\title{
Intrinsic versus Extrinsic Aging: A Histopathological, Morphometric and Immunohistochemical Study of Estrogen Receptor $\beta$ and Androgen Receptor
}

\author{
Iman Seleit ${ }^{a}$ Ola Ahmed Bakry ${ }^{a}$ Hala Saed El Repey ${ }^{b}$ Raghdaa Ali ${ }^{a}$ \\ Departments of a Dermatology, Andrology and STDs and ${ }^{b}$ Pathology, Faculty of Medicine, Menoufiya University, \\ Shibin El Koom, Egypt
}

\section{Key Words}

Estrogen receptor $\beta$. Androgen receptor · Skin aging · Immunohistochemistry

\begin{abstract}
Skin is a target organ of sex steroids which play important roles in skin health and disease. The aim of this study is to investigate the expression of estrogen receptor $\beta$ (ERß) and androgen receptor (AR) in human skin from different age groups for a better understanding of the hormonal regulation of skin aging. Using standard immunohistochemical techniques, biopsies of sun-unprotected and sun-protected skin were taken from 60 normal subjects. Sun-protected skin showed significantly higher immunoreactivity for ER $\beta$ and AR compared to sun-unprotected skin of all age groups. Significantly higher $E R \beta H$ score and percent of expression were associated with the 20-35 years age group compared to the groups that were $35-50$ years and $>50$ years old $(p<0.02$, $p=0.03$, respectively) in sun-unprotected and sun-protected skin ( $p<0.001, p=0.01$, respectively). AR H score showed a negative correlation with age $(p=0.04)$ with no significant difference in immunoreactivity in different age groups, either in sun-unprotected or sun-protected skin. There was also a significant correlation between ER $\beta \mathrm{H}$ score and epidermal thickness in sun-unprotected $(p=0.04)$ and sun-pro-
\end{abstract}

tected skin $(p=0.04)$ in studied subjects regardless of age. The same relationships did not reach significance with AR expression. However, a significant positive correlation was detected between $\mathrm{H}$ scores and percent of expression of ER $\beta$ and $A R$ in sun-unprotected ( $p=0.01, p=0.02$, respectively) and sun-protected skin ( $p=0.005, p=0.02$, respectively) regardless of age. In conclusion, both ER $\beta$ and AR decline gradually with intrinsic and extrinsic aging. This decline is more obvious with extrinsic aging. Further large-scaled studies are recommended to expand, validate and translate current findings to clinically significant, diagnostic and therapeutic applications. Molecular studies to investigate the probable ligand-independent action of both receptors are warranted. In addition, their gene expression patterns and associated signaling and metabolic pathways can also be tackled to provide a basis for further interventions in pathological processes that involve their dysregulation.

(c) 2016 S. Karger AG, Basel

\section{Introduction}

During aging, skin gradually loses its structural and functional characteristics as a consequence of time per se or because of exposure to exogenous factors such as ultraviolet and infrared radiation. The effect of the endocrine

\section{KARGER}

E-Mail karger@karger.com

www.karger.com/spp
(C) 2016 S. Karger AG, Basel

$1660-5527 / 16 / 0294-0178 \$ 39.50 / 0$
Ola Ahmed Bakry, MD

Department of Dermatology, Andrology and STDs,

Faculty of Medicine, Menoufiya University

Shibin El Koom 32817, Al Minufya (Egypt)

E-Mail olabakry8@gmail.com 
system on aging has been elucidated by several studies performed on animal and in vitro models [1-4]. Over time, important circulating hormones decline because of reduced secretion by the pituitary, adrenals and gonads or because of a concurrent disease. Amongst the numerous endocrine signals that show significant changes in blood levels with age and may directly affect the skin, androgens and estrogens play important roles [5].

Estrogen has been shown to decrease aging and wrinkling of the skin when used therapeutically [6]. It prevents aging by increasing skin thickness and dermal collagen content and strengthening the epidermal barrier [7].

There are 2 different forms of estrogen receptors, usually referred to as estrogen receptor (ER) $\alpha$ and ER $\beta$, each is encoded by a separate gene (ESR1 and ESR2, respectively) [5]. ER $\beta$ is more prevalent and predominates in skin cells while ERa is scarcely found on keratinocytes, adnexa or dermal structures $[8,9]$.

Androgens display a distinguished role in the skin. They modulate epidermal and dermal thickness, as proven in a variety of studies measuring gender-specific differences. With advanced age, changes in the circulating androgen levels may alter not only the morphology but also key functions of the skin such as epidermal barrier homeostasis, wound-healing, sebaceous gland growth and differentiation and hair growth [10].

These effects are mediated by the ligand-binding domain of estrogen receptors or androgen receptor, and can be transmitted with similar efficiency irrespective of whether the ligand is estrogen or androgen [11]. Such interactions between estrogens and androgens may be important in the control of skin physiology [12]. Therefore, the role of the estrogen and androgen receptor subtypes in skin aging needs to be determined.

This work investigates the expression of $\operatorname{ER} \beta$ and androgen receptor (AR) in sun-unprotected and sun-protected human skin from different age groups.

\section{Materials and Methods}

\section{Studied Population}

This study was carried out on 60 normal subjects, who were collected from the Plastic Surgery Outpatient Clinic, Menoufiya University Hospital during the period from March to September 2014. The study protocol was approved by the Ethical Committee, Menoufiya Faculty of Medicine. Signed informed consents were obtained from all participants prior to enrolment. This was also in accordance with the Helsinki Declaration of 1975 (revised in 2000). Clinical data describing patients' demographics (age and gender) were documented.

$\mathrm{ER} \beta$ and AR in Skin Aging

\section{Exclusion Criteria}

All subjects with $\geq 1$ diseases that may affect AR or ER expression were excluded, e.g. congenital adrenal hyperplasia, polycystic ovary (syndrome), breast cancer and androgen- or estrogen-producing tumors. Patients receiving hormone replacement therapy, oral contraceptives, topical estrogen or androgen therapy were also excluded. All selected subjects had a sedentary lifestyle.

\section{Skin Biopsies}

Two 5-mm punch skin biopsies were taken from every subject under $2 \%$ lignocaine local anesthesia; 1 from the dorsum of the hand (sun-unprotected skin) and the other from the buttock (sunprotected skin).

All biopsies were submitted to the Pathology Department, Menoufiya Faculty of Medicine. They were fixed in $10 \%$ neutral buffered formalin, dehydrated in ascending grades of ethanol, followed by immersion in xylene and then impregnated in paraffin. Serial 5 - $\mu$ m-thick sections were taken from each block. One slide was stained by hematoxylin and eosin (H\&E) for routine histopathological examination. Other sections were mounted on positivecharged slides for immunohistochemical staining.

\section{Histopathological Evaluation}

H\&E-stained sections were examined under a light microscope for assessment of the following: hyperkeratosis, hypergranulosis, epidermal thickness, flattening of dermal-epidermal junction, dilated blood vessels and the presence of inflammatory cells, melanophages and solar elastosis.

\section{Quantitative (Morphometric) Assessment of Epidermal}

Thickness

One section per patient was used for quantitative assessment. One field per section $(\times 40)$ was captured using a Leica DML B2/11888111 microscope equipped with a Leica DFC450 camera using the Leica C PLAN $4 \times 0.10$. The distance from the outermost surface of the epidermis (excluding the stratum corneum) and the dermal-epidermal junction was measured (in micrometers) at 3 different locations per section using image software, and averaged per section.

\section{Immunohistochemical Staining}

Serial sections were cut from the paraffin-embedded blocks with subsequent steps of deparaffinization and rehydration in xylene and a graded series of alcohol, respectively. Antigen retrieval was performed by boiling in $10 \mathrm{ml}$ citrate buffer ( $\mathrm{pH}$ 6.0) for 20 min, followed by cooling at room temperature. The slides were incubated overnight at room temperature using PBS with the following antibodies:

- Mouse monoclonal antibody raised against AR, supplied by Thermo Fisher Scientific Anatomical Pathology (Fremont, Calif., USA, code MS-443P0). It is supplied as a $0.1-\mathrm{ml}$ concentrate that was diluted by 1:25 according to the manufacturer's instructions.

- Rabbit polyclonal antibody raised against ER $\beta$, supplied by Thermo Fisher Scientific Anatomical Pathology (code RB10658-P1). It is supplied as $1-\mathrm{ml}$ concentrate that was diluted by 1:50 according to the manufacturer's instructions.

All slides were deparaffinized using xylene and then rehydrated in decreasing concentrations of ethanol. Antigen retrieval using microwave heating (for $20 \mathrm{~min}$ in $10 \mathrm{mmol} /$ citrate buffer, $\mathrm{pH}$ 6.0) 
Table 1. Comparison between H\&E changes in sun-unprotected and sun-protected skin

\begin{tabular}{|c|c|c|c|c|c|c|}
\hline \multirow[t]{3}{*}{ Variable } & \multicolumn{4}{|c|}{ Studied cases $(n=60)$} & \multirow[t]{3}{*}{ Test } & \multirow[t]{3}{*}{$\mathrm{p}$ value } \\
\hline & \multicolumn{2}{|c|}{ sun-unprotected skin } & \multicolumn{2}{|c|}{ sun-protected skin } & & \\
\hline & $\mathrm{n}$ & $\%$ & $\mathrm{n}$ & $\%$ & & \\
\hline \multicolumn{7}{|l|}{ Hyperkeratosis } \\
\hline Positive & 28 & 46.7 & 2 & 3.3 & $30.04^{\mathrm{a}}$ & $<0.001^{*}$ \\
\hline Negative & 32 & 53.3 & 58 & 96.7 & & \\
\hline \multicolumn{7}{|l|}{ Hypergranulosis } \\
\hline Positive & 10 & 16.7 & 1 & 1.7 & $8.11^{\mathrm{a}}$ & $0.004^{*}$ \\
\hline Negative & 50 & 83.3 & 59 & 98.3 & & \\
\hline \multicolumn{7}{|c|}{ Flattening of DEJ } \\
\hline Diffuse & 14 & 23.3 & 7 & 11.7 & $3.04^{\mathrm{a}}$ & 0.22 \\
\hline Focal & 1 & 1.7 & 2 & 3.3 & & \\
\hline Negative & 45 & 75.0 & 51 & 85.0 & & \\
\hline \multicolumn{7}{|c|}{ Dilated blood vessels } \\
\hline Positive & 24 & 40 & 10 & 16.7 & $8.04^{\mathrm{a}}$ & $0.005^{*}$ \\
\hline Negative & 36 & 60 & 50 & 83.3 & & \\
\hline \multicolumn{7}{|l|}{ Inflammation } \\
\hline Positive & 17 & 28.3 & 10 & 16.7 & $2.34^{\mathrm{a}}$ & 0.13 \\
\hline Negative & 43 & 71.7 & 50 & 83.3 & & \\
\hline \multicolumn{7}{|l|}{ Melanophages } \\
\hline Positive & 0 & 0 & 0 & 0 & - & - \\
\hline Negative & 60 & 100 & 60 & 100 & & \\
\hline \multicolumn{7}{|l|}{ Solar elastosis } \\
\hline Positive & 23 & 38.3 & 8 & 13.3 & $9.79^{\mathrm{a}}$ & $0.002^{*}$ \\
\hline Negative & 37 & 61.7 & 52 & 86.7 & & \\
\hline \multicolumn{7}{|c|}{ Epidermal morphometry } \\
\hline Mean \pm SD & \multirow{2}{*}{\multicolumn{2}{|c|}{$\begin{array}{l}230.90 \pm 66.47 \\
88.68-372.24\end{array}$}} & \multirow{2}{*}{\multicolumn{2}{|c|}{$\begin{array}{l}160.34 \pm 61.22 \\
86.1-354.22\end{array}$}} & $5.61^{b}$ & $<0.001^{*}$ \\
\hline Range & & & & & & \\
\hline
\end{tabular}

$\mathrm{DEJ}=$ Dermal-epidermal junction; $\mathrm{SD}=$ standard deviation. ${ }^{*}$ Significant. ${ }^{\mathrm{a}} \chi^{2}$ test. ${ }^{\mathrm{b}}$ Mann-Whitney $\mathrm{U}$ test.

after inhibition of endogenous peroxidase activity (hydrogen peroxidase for $15 \mathrm{~min}$ ) was used. The primary antibody was applied to the slides and incubated overnight at room temperature in a humidity chamber. Sections were then washed with PBS, incubated with the secondary antibody for 15 min and followed by a PBS wash. Finally, the detection of bound antibody was accomplished using a modified, labeled avidin-biotin (LAB) reagent for $20 \mathrm{~min}$, then a PBS wash. A $0.1 \%$ solution of diaminobenzidine (DAB) was used for $5 \mathrm{~min}$ as a chromogen. Slides were counterstained with Mayer's hematoxylin for 5-10 min.

\section{Interpretation of Immunohistochemical Results}

A brown nuclear staining in any number of cells was considered positive in the studied normal skin biopsies [13, 14].

The epidermis (keratinocytes) and dermis (adnexa, endothelial cells, fibroblasts and inflammatory cells) were assessed separately for the expression of $\mathrm{AR}$ and $\mathrm{ER} \beta$ being either positive or negative.

The epidermis was also assessed for:

- Intensity of the stain: mild (+), moderate $(++)$ or strong $(+++)$.
- Expression percentage: positive cells were counted and given a percentage over 200 basal cells of the whole section at a $\times 200$ magnification [15].

- Histo-score (H score): $\mathrm{H}$ score was calculated in all positive specimens according to the following equation [16]:

$\mathrm{H}$ score $=1 \times \%$ of mildly stained cells $+2 \times \%$ of moderately stained cells $+3 \times \%$ of strongly stained cells.

\section{Statistical Analysis}

Data were collected, tabulated and statistically analyzed using a personal computer with SPSS v22 (SPSS Inc., Chicago, Ill., USA). Fisher's exact test was used for the comparison of qualitative variables in $2 \times 2$ tables when the expected cell count of $>25 \%$ of cases was $<5$. The $\chi^{2}$ test was used to study the association between 2 qualitative, normally distributed variables. The Mann-Whitney U test was used for the comparison between 2 groups not normally distributed and having quantitative variables. Spearman's coefficient was used to measure the correlation between 2 quantitative variables. Differences were considered statistically significant when $\mathrm{p}<0.05$. 
Table 2. Immunohistochemical expression of ER $\beta$ and $A R$ in sun-unprotected and sun-protected skin

\begin{tabular}{|c|c|c|c|c|c|c|c|c|}
\hline Variable & \multicolumn{4}{|l|}{$\mathrm{ER} \beta$} & \multicolumn{4}{|l|}{$\mathrm{AR}$} \\
\hline \multicolumn{9}{|l|}{ Epidermis } \\
\hline \multicolumn{9}{|l|}{ Keratinocytes } \\
\hline \multicolumn{9}{|l|}{ Pattern } \\
\hline Cytoplasmic & $36(66.7)$ & $21(37.5)$ & $9.37^{\mathrm{b}}$ & $0.002^{*}$ & $40(88.9)$ & $41(73.2)$ & $3.86^{\mathrm{b}}$ & $0.049^{*}$ \\
\hline Nucleocytoplasmic & $18(33.3)$ & $35(62.5)$ & & & $5(11.1)$ & $15(26.8)$ & & \\
\hline \multicolumn{9}{|l|}{ Intensity } \\
\hline Mild & $19(35.2)$ & $9(16.1)$ & $7.94^{\mathrm{b}}$ & $0.02 *$ & $20(44.4)$ & $8(14.3)$ & $16.2^{\mathrm{b}}$ & $<0.001^{*}$ \\
\hline Moderate & $30(55.6)$ & $33(58.9)$ & & & $25(55.6)$ & $39(69.6)$ & & \\
\hline \multicolumn{9}{|l|}{ Percentage } \\
\hline \multicolumn{9}{|l|}{ H score } \\
\hline Mean \pm SD & $102.87 \pm 66.56$ & $144.82 \pm 68.05$ & $3.36^{\mathrm{a}}$ & $0.001^{*}$ & $98.0 \pm 46.25$ & $149.29 \pm 50.84$ & $4.63^{\mathrm{a}}$ & $<0.001^{*}$ \\
\hline Range & $20-270$ & $30-270$ & & & $20-180$ & $30-270$ & & \\
\hline \multicolumn{9}{|l|}{ Dermis } \\
\hline \multicolumn{9}{|l|}{ Endothelium } \\
\hline Positive & $0(0.0)$ & $0(0.0)$ & - & - & $0(0.0)$ & $0(0.0)$ & - & - \\
\hline Negative & $60(100)$ & $60(100)$ & & & $60(100)$ & $60(100)$ & & \\
\hline \multicolumn{9}{|l|}{ Fibroblasts } \\
\hline Positive & $3(5)$ & $5(8.3)$ & $0.54^{\mathrm{c}}$ & 0.72 & $0(0.0)$ & $0(0.0)$ & - & - \\
\hline Negative & $57(95)$ & $55(91.7)$ & & & $60(100)$ & $60(100)$ & & \\
\hline Sweat glands & $(\mathrm{n}=36)$ & $(\mathrm{n}=31)$ & & & $(\mathrm{n}=47)$ & $(\mathrm{n}=50)$ & & \\
\hline Negative & $16(94.1)$ & $15(75)$ & & & $37(90.2)$ & $35(81.4)$ & & \\
\hline
\end{tabular}

Values denote $\mathrm{n}(\%)$, unless otherwise indicated. SD = Standard deviation. ${ }^{*}$ Significant.

${ }^{a}$ Mann-Whitney $U$ test. ${ }^{b} \chi^{2}$ test. ${ }^{c}$ Fisher's exact test.

\section{Results}

The study group consisted of 60 normal subjects whose age ranged from 20 to 66 years $(39.17 \pm 11.27$ years). There were 39 males (65\%) and 21 females (35\%); females included $14(66.7 \%)$ premenopausal and 7 (33.3\%) postmenopausal subjects. They were divided according to age: group $\mathrm{I}=20-35$ years, group II $=35-50$ years and group III $=>50$ years.

$\mathrm{ER} \beta$ and AR in Skin Aging

\section{Histopathological Findings}

The results of $\mathrm{H} \& \mathrm{E}$-stained sections are demonstrated in table 1 and online supplementary figure 1 (see www. karger.com/doi/10.1159/000446662 for all online suppl. material).

\section{Morphometric Findings}

Quantitative assessment of epidermal thickness is demonstrated in table 1. Epidermal thickness decreased 

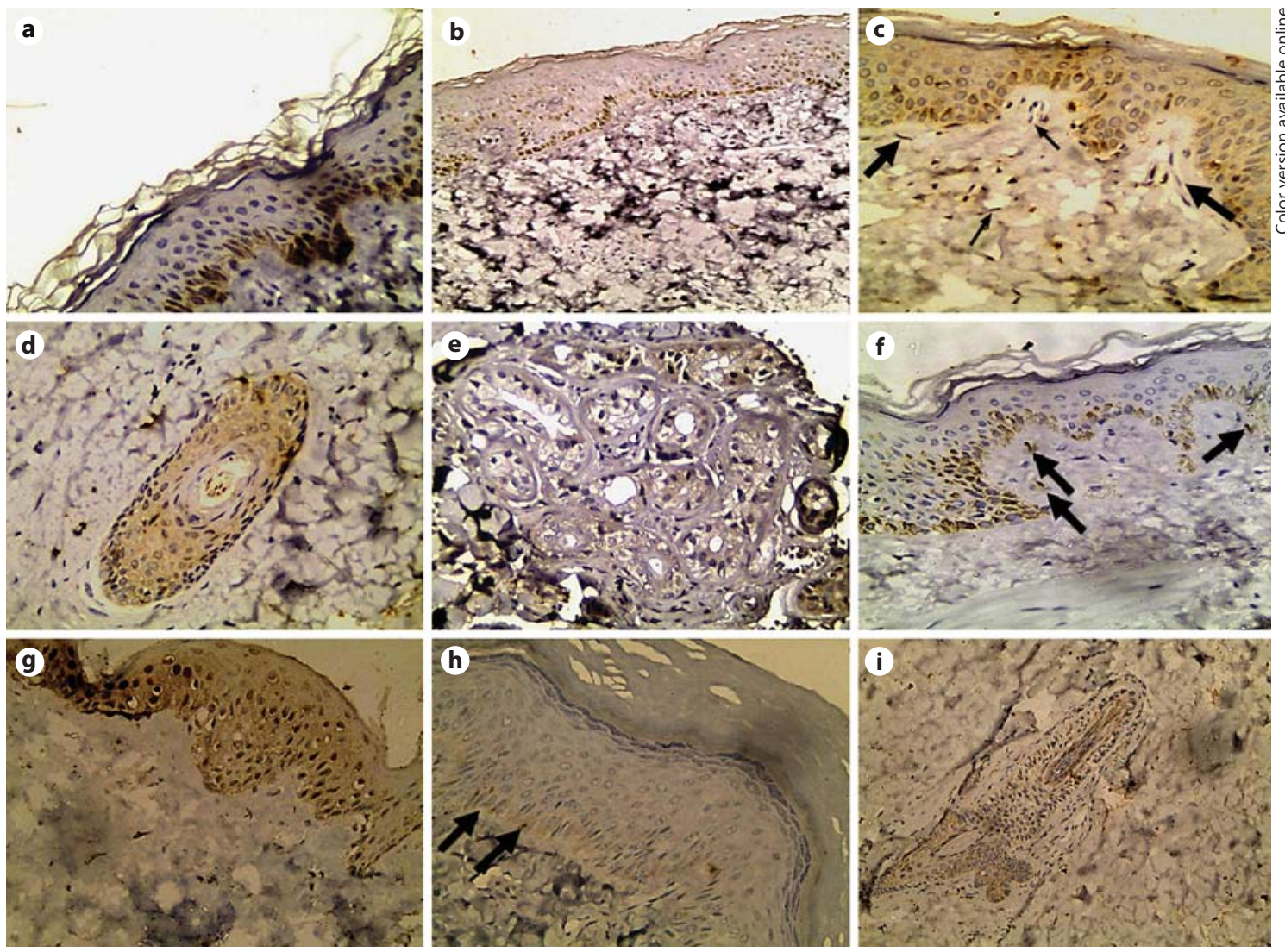

Fig. 1. a-f ER $\beta$ expression in sun-protected skin. a Strong nucleocytoplasmic expression in epidermis (20-year-old male). b Moderate nucleocytoplasmic expression in epidermis (40-year-old male). c Mild nucleocytoplasmic expression in epidermis while both dermal fibroblasts (thick arrows) and endothelial cells (thin arrows) were ER $\beta$-negative (55-year-old female). d Positive cytoplasmic expression in hair follicle (42-year-old female). e Mild positive cytoplasmic expression in sweat glands (42-year-old male). f Positive expression in dermal fibroblasts (arrows) and overlying epidermis (27-year-old male). g-i ER $\beta$ expression in sun-unprotected skin. g Strong nucleocytoplasmic ER $\beta$ expression in epidermis (32-yearold male). h Focal mild cytoplasmic expression (arrows) in basal layer of epidermis (65-year-old male). i Mild cytoplasmic expression in hair follicle (40-year-old female). Immune peroxidase. $\times 400$, except for $\mathbf{d}, \mathbf{g}, \mathbf{i}: \times 200$. gradually with age both in sun-unprotected and sun-protected skin (data not shown in tables).

\section{Immunohistochemical Expression of $A R$ and $E R \beta$}

ER $\beta$ epidermal expression was positive in 90 and 93.3\% of sun-unprotected and sun-protected skin, respectively. The pattern was either cytoplasmic or nucleocytoplasmic and intensity varied from mild to strong. Dermal ER $\beta$ showed variable reactivity in the examined fibroblasts in sun-unprotected and sun-protected skin. ER $\beta$ was expressed in basal and differentiated sebocytes and in hair follicle structures including the inner and outer root sheaths, bulge region and dermal papilla. Detailed $\mathrm{ER} \beta$ expression in examined specimens is demonstrated in table 2 and figure 1.
AR epidermal expression was positive in 75 and $93.3 \%$ of sun-unprotected and sun-protected skin, respectively. The pattern was cytoplasmic or nucleocytoplasmic. Intensity of expression varied from mild to moderate in sun-unprotected skin and from mild to strong in sunprotected skin. Dermal AR showed positive immunoreactivity in basal and differentiated sebocytes and in hair follicle structures including the inner and outer root sheaths, bulge region and dermal papilla. AR showed negative immunoreactivity in endothelial cells, fibroblasts and sweat glands both in sun-unprotected and sun-protected skin. Detailed AR expression in the examined specimens is demonstrated in table 2 and figure 2. 

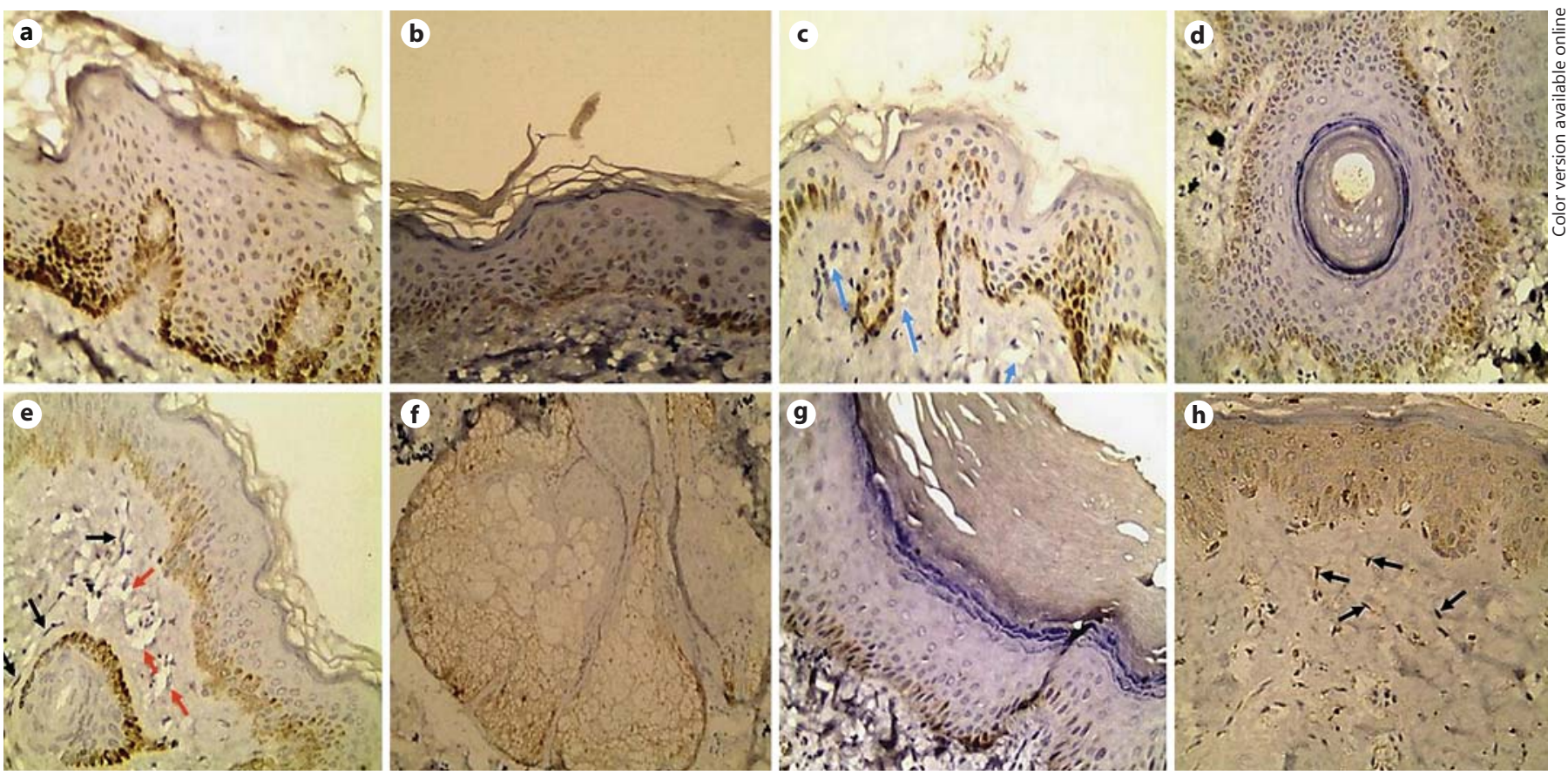

Fig. 2. a-f AR expression in sun-protected skin. a Strong nucleocytoplasmic expression in epidermis (25-year-old female). b Moderate nucleocytoplasmic expression in epidermis (45-year-old male). c Strong nucleocytoplasmic AR expression in epidermis and negative expression in endothelial cells (arrows) (32-year-old female). d Mild cytoplasmic expression in hair follicle (50-year-old male). e Positive expression in epidermis and hair follicles and

negative expression in endothelial cells (red arrows) and fibroblasts (black arrows) (56-year-old male). $\mathbf{f}$ Positive expression in sebaceous glands (41-year-old male). $\mathbf{g}, \mathbf{h}$ AR expression in sununprotected skin. $\mathbf{g}$ Moderate nucleocytoplasmic expression in epidermis (40-year-old male). $\mathbf{h}$ Focal positive expression in epidermis and fibroblasts (arrows) (42-year-old male). Immunoperoxidase. $\times 400$, except for $\mathbf{e}, \mathbf{h}: \times 200$. For colors, see online version.

\section{Comparison between Immunohistochemical}

Expression of ER $\beta$ and $A R$ in the Epidermis and

Dermis in Sun-Unprotected and Sun-Protected Skin in the Different Age Groups

\section{Estrogen Receptor $\beta$}

Nucleocytoplasmic pattern ( $\mathrm{p}=0.002)$, strong intensity $(\mathrm{p}=0.02)$, higher $\mathrm{H}$ score $(\mathrm{p}=0.001)$ and higher percent of expression $(\mathrm{p}=0.009)$ were significantly associated with sun-protected compared to sun-unprotected skin (table 2).

$\mathrm{ER} \beta$ epidermal $\mathrm{H}$ score and percent of expression showed a gradual decline from the $20-35$ years group to the $35-50$ years group, with the least immunoreactivity in the $>50$ years group, both in sun-unprotected and sunprotected skin. Significantly higher $\mathrm{H}$ score and percent of expression were associated with the 20-35 years group ( $p<0.02, p=0.03$, respectively) in sun-unprotected and sun-protected skin $(\mathrm{p}<0.001, \mathrm{p}=0.01$, respectively; fig. 3).

ER $\beta$ and AR in Skin Aging
There was no significant difference in ER $\beta$ immunoreactivity between premenopausal and postmenopausal females in sun-unprotected and sun-protected skin (data not shown in tables).

Higher $\mathrm{H}$ score was significantly demonstrated in sunprotected skin in the 20-35 years group ( $\mathrm{p}=0.02), 35-50$ years group $(\mathrm{p}=0.04)$ and $>50$ years group $(\mathrm{p}=0.03)$ than in sun-unprotected skin of the corresponding age groups (fig. 4).

\section{Androgen Receptor}

Sun-protected skin showed significantly higher keratinocyte expression $(\mathrm{p}=0.006)$, stronger intensity $(\mathrm{p} \leq$ $0.001)$, a higher percent of expression $(\mathrm{p}=0.006)$ and a higher $\mathrm{H}$ score $(\mathrm{p} \leq 0.001)$. Cytoplasmic pattern was significantly associated with sun-unprotected skin ( $\mathrm{p}=$ 0.049; table 2).

No significant difference was noted in AR immunoreactivity in different age groups in sun-unprotected or sun-protected skin. There was also no significant differ- 


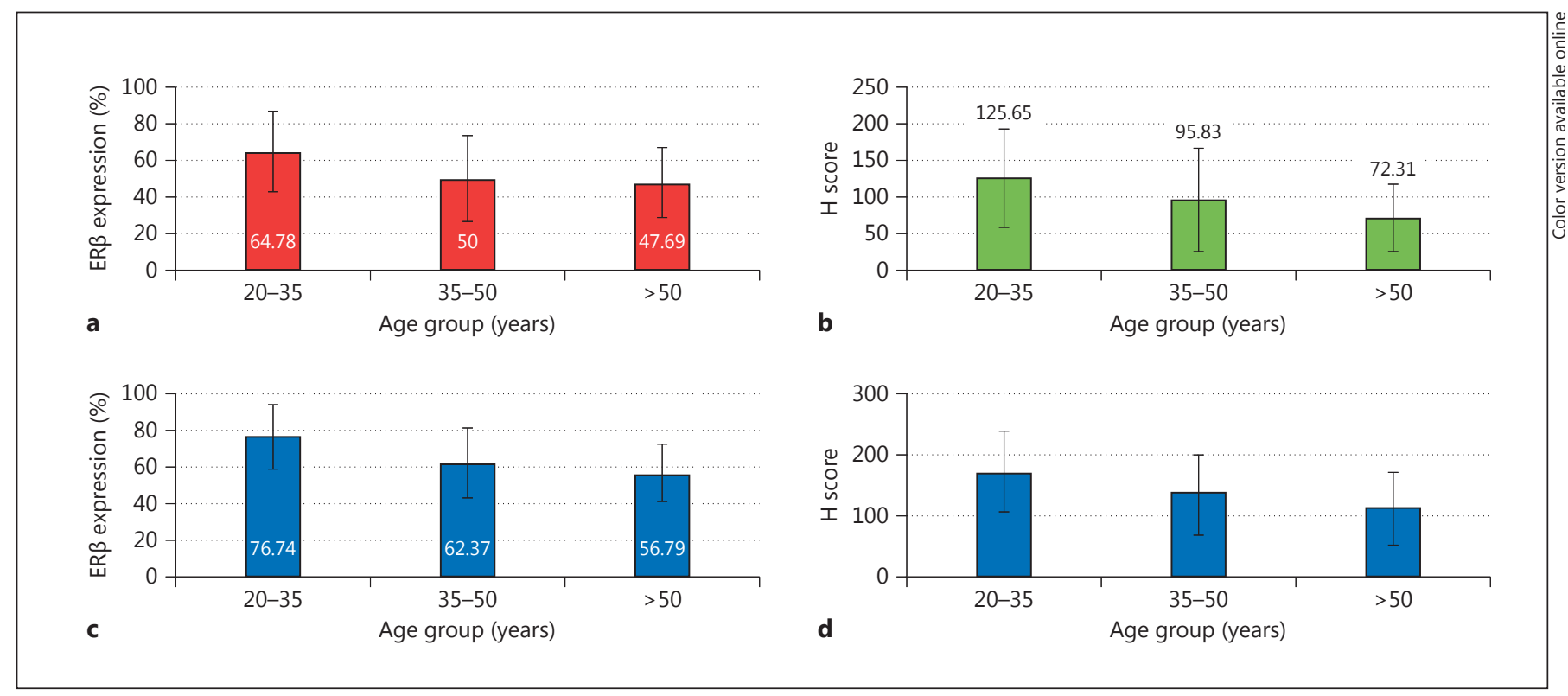

Fig. 3. Comparison of immunohistochemical expression of $\operatorname{ER} \beta$ in epidermis in different age groups. In sununprotected skin, a higher percentage of expression (a) and higher $\mathrm{H}$ score (b) were significantly associated with the age group 20-35 years. In sun-protected skin, a higher percentage of expression (c) and higher $\mathrm{H}$ score (d) were significantly associated with the age group $20-35$ years.

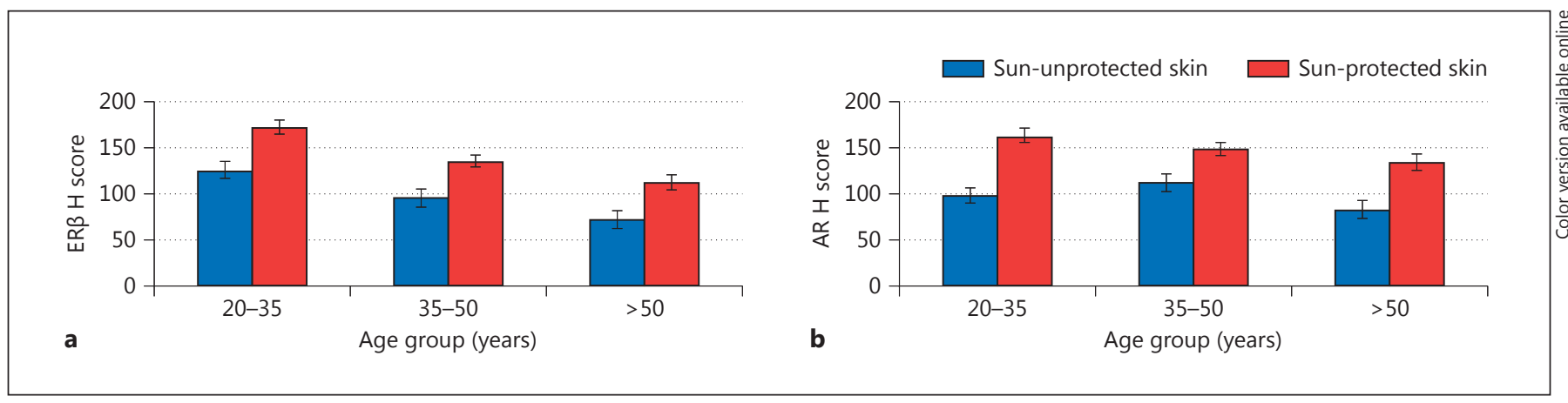

Fig. 4. a, b Comparison between immunohistochemical expression of ER $\beta$ and AR in sun-unprotected and sunprotected skin in different age groups. Higher $\mathrm{H}$ score was significantly associated with sun-protected skin in all 3 age groups for both $\mathrm{ER} \beta$ and AR.

ence in AR immunoreactivity between premenopausal and postmenopausal females in sun-unprotected or sunprotected skin (data not shown in tables).

Higher epidermal $\mathrm{H}$ score was significantly demonstrated in sun-protected skin in the $20-35$ years group $(\mathrm{p} \leq 0.001), 35-50$ years group $(\mathrm{p}=0.03)$ and $>50$ years group $(\mathrm{p}=0.03)$ than in sun-unprotected skin of the corresponding age groups (fig. 4 ).
Comparison between ER $\beta$ and $A R$ Expression in Male and Female Subjects

No significant difference was detected in ER $\beta$ and AR expression in male and female subjects in sun-unprotected or sun-protected skin (online suppl. tables 1,2).

\section{Correlation between ER $\beta$ and $A R H$ Scores and}

Percentage of Expression and Age

There was a significant negative correlation between age and ER $\beta$ percentage of expression $(r=-0.35, p=$ 


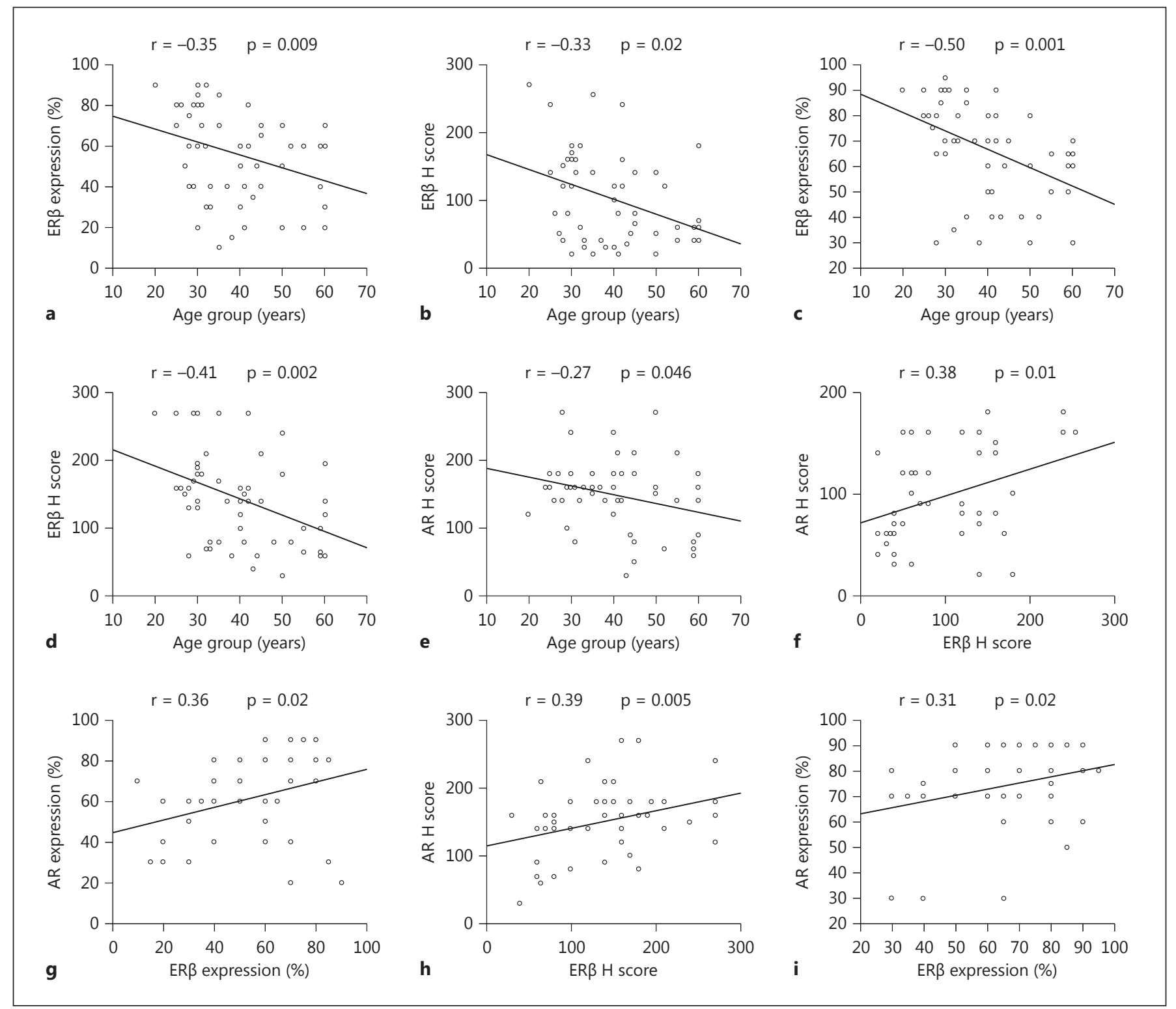

Fig. 5. Significant negative correlation between age and ER $\beta$ expression (a) and ER $\beta$ H score (b) in sun-unprotected skin. Significant negative correlation between age and ER $\beta$ expression (c) and $\operatorname{ER} \beta \mathrm{H}$ score $(\mathbf{d})$ in sun-protected skin. e Significant negative correlation between AR $\mathrm{H}$ score and age of studied subjects in sun- protected skin. Significant positive correlation between ER and AR $\mathrm{H}$ score (f) and percent values (g) in sun-unprotected skin. Significant positive correlation between ER and AR H score (h) and percent values (i) in sun-protected skin.
$0.009)$ and between age and $\operatorname{ER} \beta \mathrm{H}$ score $(\mathrm{r}=-0.33, \mathrm{p}=$ $0.02)$ in sun-unprotected and in sun-protected skin $(\mathrm{r}=-0.50, \mathrm{p} \leq 0.001$ and $\mathrm{r}=-0.41, \mathrm{p}=0.002$, respectively; fig. 5). A significant negative correlation was detected between age and $\mathrm{AR} \mathrm{H}$ score in sun-protected skin $(\mathrm{r}=-0.27, \mathrm{p}=0.046$; fig. 5).

\section{Relationship between $A R$ and ER $\beta$ Expression and Morphometric Data}

There was a significant positive correlation between $\mathrm{H}$ score of ER $\beta$ and epidermal thickness in sun-unprotected and sun-protected-skin ( $\mathrm{p}=0.04$ for both) in the studied subjects regardless of age and in the $>50$ years group $(\mathrm{p}=$ 0.04 for both; table 3 ). The same relationship did not 
Table 3. Correlation between epidermal morphometry and ER $\beta \mathrm{H}$ score and percentage values in sun-unprotected and sun-protected skin of studied subjects

\begin{tabular}{|c|c|c|c|c|c|c|c|c|}
\hline & \multicolumn{2}{|c|}{ Total } & \multicolumn{2}{|c|}{$20-35$ years } & \multicolumn{2}{|c|}{$35-50$ years } & \multicolumn{2}{|c|}{$>50$ years } \\
\hline Percentage & 0.25 & 0.23 & 0.13 & 0.78 & 0.23 & 0.47 & 0.18 & 0.56 \\
\hline H score & 0.38 & $0.04^{*}$ & 0.22 & 0.61 & 0.11 & 0.87 & 0.51 & $0.04^{*}$ \\
\hline Percentage & 0.04 & 0.77 & 0.29 & 0.23 & 0.25 & 0.34 & 0.33 & 0.18 \\
\hline H score & 0.31 & $0.04^{*}$ & 0.25 & 0.31 & 0.28 & 0.27 & 0.44 & $0.04^{*}$ \\
\hline
\end{tabular}

* Significant. $\mathrm{r}=$ Correlation coefficient.

reach significance with AR expression in sun-unprotected and sun-protected skin (data not shown in tables).

\section{Correlation between ER $\beta$ and $A R H$ Scores and \\ Percentage Values in Sun-Unprotected and}

Sun-Protected Skin

A significant positive correlation was noted between $\mathrm{ER} \beta$ and $\mathrm{AR} H$ scores and percentage values in the studied subjects regardless of age $(\mathrm{r}=0.38, \mathrm{p}=0.01$ and $\mathrm{r}=$ $0.36, \mathrm{p}=0.02$, respectively) in sun-unprotected and sunprotected skin $(\mathrm{r}=0.39, \mathrm{p}=0.005$ and $\mathrm{r}=0.31, \mathrm{p}=0.02$, respectively; fig. 5).

\section{Discussion}

In this work, keratinocytes showed positive ER $\beta$ expression in both sun-unprotected and sun-protected skin, mainly in the basal layer with variable suprabasal immunoreactivity. These results were consistent with previous studies $[9,17]$. Estradiol can stimulate both epidermal keratinocyte proliferation and DNA synthesis [18]. Kanda and Watanabe [19] demonstrated that estradiol suppresses apoptosis in keratinocytes by promoting $\mathrm{Bcl}-2$ expression and induces the expression of cyclin D2, an important cell-cycle regulatory protein [20]. Estrogen may also play a role in the stratum corneum barrier function [21-24].

The positive ER $\beta$ immunoreactivity in normal skin fibroblasts, noted here, was similarly reported before $[25$, $26]$. ER $\beta$ expression in fibroblasts, the major producers of type I collagen, strongly suggests that estrogen directly affects fibroblast biology through receptor-mediated effects [27]. This is brought through promoting fibroblast transforming growth factor $\beta$ (TGF- $\beta$ ) production [28]. TGF- $\beta$ is a multifunctional cytokine that stimulates fibroblast proliferation in the dermis, induces the synthesis and secretion of the major extracellular matrix proteins and downregulates the expression of proteolytic enzymes, such as collagenase and stromelysin [29]. Consistent with this view, it has been reported that cultured mouse dermal fibroblasts increase collagen synthesis in response to estrogen [30, 31].

In this study, ER $\beta$ immunoreactivity was detected in basal and differentiated sebocytes. Similar findings were reported previously [10]. Studies using cultured human sebaceous glands have shown that physiological levels of estradiol significantly decrease lipogenesis without affecting the rate of cell division [32].

Our results also showed positive ER $\beta$ expression in hair follicle structures including the inner and outer root sheaths, bulge region and dermal papilla. The bulge region contains the stem cells for hair follicle keratinocytes [33]. Therefore, these results may provide evidence that estradiol mediates its effects on hair follicle through the direct regulation of stem cells; this suggests an important role for estrogens in the regulation of hair growth. The role of estrogens in the regulation of eccrine sweat glands which express ER $\beta$ is still unknown [10]. Therefore, the positive immunoreactivity that we detected requires further investigation in order to be clarified.

We found that ER $\beta \mathrm{H}$ score and percentage of expression showed a gradual decline with advancing age. This is in agreement with Inoue et al. [34], who showed a sig- 
nificant decrease in its epidermal expression in subjects $>70$ years old. In addition, ERB H score values and percentage of expression were negatively correlated with age in sun-unprotected and sun-protected skin. A significant positive correlation between ER $\beta \mathrm{H}$ score and epidermal thickness in sun-unprotected and sun-protected skin was also detected.

It is well known that, with aging, there is a decline in the level of sex hormones including estrogens [35]. This hormonal decline is accompanied by significant changes within the skin [36]. Skin cellular renewal becomes sluggish, collagen production is reduced and its distribution is altered, resulting in thinning of the epidermal and dermal layers and the ability of the skin to maintain its barrier function and its hydration, strength and elasticity suffer as a result $[37,38]$. From our results, we come to the conclusion that not only estrogen hormone but also its functioning receptor, $E R \beta$, is downregulated with age.

Cerdà et al. [39] showed that the number of ERs declines with the onset of menopause in women. However, there was no significant difference between pre- and postmenopausal women in our work. This may be due to the small number of studied female subjects.

We detected positive epidermal AR expression in sununprotected and sun-protected skin, and this was mainly in the basal layer with variable suprabasal immunoreactivity. These results agree with previous studies [40]. The expression of $\mathrm{AR}$ in the epidermis indicates that keratinocytes are target cells for androgen action on the skin. The role of androgens on the activity of kerantiocytes remains to be clarified. However, the presence of AR-expressing keratinocytes within the pilosebaceous ducts supports the hypothesis that androgens can directly influence keratinization [41]. It has been stated that AR can modulate the proliferation and differentiation of epithelial cells of the epidermis and adnexa, the functional activity of dermal fibroblasts [42] and dermal angiogenesis [43].

Androgens have strong effects on hair growth and appear to act through AR and type II $5 \alpha$-reductase on dermal papilla cells [44]. AR gene polymorphisms have been associated with hirsutism in women [45] and androgenetic alopecia in men [46]. Dermal papilla cells appear to mediate the growth-stimulating signals of androgens by releasing growth factors that act in a paracrine fashion on the other cells of the follicle [47]. However, overexpression of the AR promotes androgen-induced premature senescence of dermal papilla cells [48].

Androgens cause the enlargement of hair follicles in androgen-dependent areas, but in the scalp follicles of susceptible men, paradoxically, androgens foster miniaturization and shortage of hair in the anagen stage that commonly leads to baldness [49]. These contradictory effects may be explained by genetically determined differences in the response of the papilla cells to androgens in different body areas [27]. Nevertheless, the positive expression of both AR and ER $\beta$ in the hair follicle structures including the inner and outer root sheaths, bulge region and dermal papilla, that we detected, requires further investigation to determine whether androgen metabolites, acting over ER $\beta$, affect follicular dermal papilla cells, as occurs in the mouse prostate $[9,50]$.

It is well accepted that testicular and adrenal androgens decline progressively with aging in men [51, 52]. However, in women, this issue is controversial and has been under much debate $[53,54]$. In this work, AR expression was negatively correlated with age but did not show a meaningful difference across the different age groups or between pre- and postmenopausal females. Further, larger-scale studies are recommended.

In this study, ER $\beta$ and AR showed higher expression in sun-protected than in sun-unprotected skin. This finding has not been commented on in similar studies and its significance is not clear. The effect of UV radiation on sex steroids and their receptor expression has been proved in animals but not in humans [55]. However, the downregulation noted in sun-unprotected skin with advancing age may provide evidence that deficient receptor expression occurs in both the intrinsic and extrinsic aging processes. This finding corresponds to the fact that skin aging is a degenerative process whereby alterations due to the passage of time (chronological/intrinsic aging) are superimposed with effects produced by environmental factors, the most important of which is UV radiation $[56,57]$.

It is worthy to note that sex steroid receptors proved to have ligand-independent actions [58]. Questions now arise. Does the downregulation of $A R$ and $E R \beta$, as we have demonstrated, have further unknown hormonal-independent effects that play a role in the deterioration of the skin with aging? Does ER $\beta$ downregulation have a role in hair aging, especially in females? Further molecular in vitro and in vivo studies are required to demystify these issues.

ERs and AR are known to exhibit nuclear immunoreactivity [59]. In our study, the nucleocytoplasmic pattern of both $E R \beta$ and AR was detected. It was postulated that androgens and other sex steroids may affect cells via mechanisms that do not involve gene transcription/expression, but the activation of cytoplasmic signaling pathways that affect cell survival and/or modulate other 
growth factor signaling $[60,61]$. Parker [62] concluded that ERs can move between the nucleus and the cytoplasm, but under normal conditions they are predominantly located in the nucleus. Pelletier and Ren [12] detected nucleocytoplasmic ER $\beta$ immunoreactivity in ducts of eccrine sweat glands. Heemers and Tindall [63] concluded that AR, in its inactive form, is located in the cytoplasm of the cell in complex with heat-shock proteins. Upon ligand binding, AR homodimerizes and translocates to the nucleus where it binds to the specific sequences on the DNA known as androgen response elements. It may also recruit cofactors (proteins) that either enhance or reduce AR transactivation [64].

The lack of significant differences between male and female subjects regarding AR and ER $\beta$ expression that we noted needs to be confirmed by additional large-scale studies investigating different sites on the body. The regional differences in receptor density or activity in both genders have not been investigated before.

Our work showed a significant positive correlation between ER $\beta$ and AR H scores and expression percentage in both sun-unprotected and sun-protected skin. This is in line with the hypothesis that tissues traditionally thought to be responsive to one class of steroids, contain receptors for other classes, and that steroid receptors can cross-talk with one another $[65,66]$.

From the aforementioned findings, both ER $\beta$ and AR decline gradually with intrinsic and extrinsic aging. This decline is more obvious with extrinsic aging. Further large-scale studies are recommended to be able to expand, validate and translate the current findings to clinically significant diagnostic and therapeutic applications. Studies are also needed to clarify the physiological role of androgens and AR on keratinocytes. With new investigative techniques, perhaps now is the time to readdress many of the outstanding questions regarding their role in skin aging. Molecular studies to investigate the probable ligand-independent action of both receptors are also warranted. In addition, gene expression patterns and associated signaling and metabolic pathways of ER $\beta$ and AR can also be tackled to provide a basis for further interventions in pathological processes that involve their dysregulation.

\section{Statement of Ethics}

Taking samples was done after obtaining written consent from the patients and control subjects.

\section{Disclosure Statement}

The authors have no conflicts of interest that are directly relevant to the content of this study. No sources of funding were used to conduct this study or prepare the manuscript.

\section{References}

1 Gems D, Partridge L: Insulin/IGF signalling and ageing: seeing the bigger picture. Curr Opin Genet Dev 2001;11:287-292.

$\checkmark 2$ Bartke A, Coschigano K, Kopchick J, et al: Genes that prolong life: relationships of growth hormone and growth to aging and life span. J Gerontol A Biol Sci Med Sci 2001; 56:B340-B349.

3 Simon AF, Shih C, Mack A, Benzer S: Steroid control of longevity in Drosophila melanogaster. Science 2003;299:1407-1410.

4 Tatar M, Bartke A, Antebi A: The endocrine regulation of aging by insulin-like signals. Science 2003;299:1346-1351.

5 Makrantonaki E, Schönknecht P, Hossini AM, et al: Skin and brain age together: the role of hormones in the ageing process. Exp Gerontol 2010;45:801-813.

6 Wolff EF, Narayan D, Taylor HS: Long-term effects of hormone therapy on skin rigidity and wrinkles. Fertil Steril 2005;84:285-288.

7 Quatresooz P, Pierard GE: Downgrading skin climacteric aging by hormone replacement therapy. Expert Rev Dermatol 2007;2:373-376.
Li X, Huang J, Yi P, et al: Single-chain estrogen receptors (ERs) reveal that the ERalpha/ beta heterodimer emulates functions of the ERalpha dimer in genomic estrogen signaling pathways. Mol Cell Biol 2004;24:7681-7694.

-9 Ohata C, Tadokoro T, Itami S: Expression of estrogen receptor beta in normal skin, melanocytic nevi and malignant melanomas. J Dermatol 2008;35:215-221.

10 Makrantonaki E, Zouboulis CC: Androgens and ageing of the skin. Curr Opin Endocrinol Diabetes Obes 2009;16:240-245.

11 Weihua Z, Makela S, Andersson LC, et al: A role for estrogen receptor beta in the regulation of growth of the ventral prostate. Proc Natl Acad Sci USA 2001:98:6330-6335.

$\checkmark 12$ Pelletier G, Ren L: Localization of sex steroid receptors in human skin. Histol Histopathol 2004:19:629-636

13 Pelletier G, Labrie C, Labrie F: Localization of oestrogen receptor alpha, oestrogen receptor beta and androgen receptors in the rat reproductive organs. J Endocrinol 2000;165:359370 .
14 Taylor Ah, Al- Azzawi F: Immunolocalization of estrogen receptor beta in human tissues. J Mol Endocrinol 2000;24:145-155.

15 Bahnassy AA, Zekri AR, El-Houssini S, et al: Cyclin A and cyclin D1 as significant prognostic markers in colorectal cancer patients. BMC Gastroenterol 2004;23:4-22.

16 Bilalovic N, Sandstad B, Golouh R, et al: CD10 protein expression in tumor and stromal cells of malignant melanoma is associated with tumor progression. Mod Pathol 2004;17:12511258.

17 Kanda N, Watanabe S: 17beta-Estradiol inhibits the production of RANTES in human keratinocytes. J Invest Dermatol 2003;120: 420-427.

18 Punnonen R: Effect of castration and peroral estrogen therapy on the skin. Acta Obstet Gynecol Scand Suppl 1972:21:3-44.

19 Kanda N, Watanabe S: 17beta-Estradiol inhibits oxidative stress-induced apoptosis in keratinocytes by promoting $\mathrm{Bcl}-2$ expression. J Invest Dermatol 2003:121:1500-1509. 
20 Kanda N, Watanabe S: 17beta-Estradiol stimulates the growth of human keratinocytes by inducing cyclin D2 expression. J Invest Dermatol 2004:123:319-328.

-21 Pierard-Franchimont C, Letawe C, Goffin V, et al: Skin water-holding capacity and transdermal estrogen therapy for menopause/a pilot study. Maturitas 1995:22:151-154.

22 Verdier-Sevrain S, Yaar M, Cantatore J, et al: Estradiol induces proliferation of keratinocytes via receptor-mediated mechanisms. FASEB J 2004:11:1252-1254.

23 Guy RH: Skin - 'that unfakeable young surface'. Skin Pharmacol Physiol 2013;26:181-189.

24 Grice J, Benson HA: Analysing the skin barrier from down under. Skin Pharmacol Physiol 2013;26:254-262.

25 Haczynski J, Tarkowski R, Jarzabek K, et al: Human cultured skin fibroblasts express estrogen receptor alpha and beta. Int J Mol Med 2002;10:149-153.

-26 Walker VR, Korach KS: Estrogen receptor knockout mice as a model for endocrine research. ILAR J 2004;45:455-461.

27 Thornton MJ, Taylor AH, Mulligan K, et al: The distribution of estrogen receptor beta is distinct to that of estrogen receptor alpha and the androgen receptor in human skin and the pilosebaceous unit. J Investig Dermatol Symp Proc 2003;8:100-103.

-28 Ashcroft GS, Dodsworth J, van Boxtel E, et al: Estrogen accelerates cutaneous wound healing associated with an increase in TGF-betal levels. Nat Med 1997;3:1209-1215.

29 Hall MC, Young DA, Waters JG, et al: The comparative role of activator protein 1 and Smad factors in the regulation of TIMP-1 and MMP-1 gene expression by transforming growth factor-beta 1. J Biol Chem 2003;278: 10304-10313.

-30 Hosokawa M, Ishii M, Inoue K, et al: Estrogen induces different responses in dermal and lung fibroblasts: special reference to collagen. Connect Tissue Res 1981;9:115-120.

31 Thornton MJ: The biological actions of estrogens on skin. Exp Dermatol 2002;11:487-502.

32 Guy R, Ridden C, Kealy T: The improved organ maintenance of the human sebaceous gland: modeling in vitro the effects of epidermal growth factor, androgens, estrogens, $13-$ cis retinoic acid, and phenol red. J Invest Dermatol 1996;106:454-460.

33 Cotsarelis G: Hair follicle stem cells: their location and roles; in Camacho FM, Randall VA (eds): Hair and Its Disorders, Biology, Pathology and Management. London, Martin Dunitz, 2000, pp 39-47.

34 Inoue T, Miki Y, Abe K, et al: The role of estrogen-metabolizing enzymes and estrogen receptors in human epidermis. Mol Cell Endocrinol 2011;344:35-40.

-35 Verdier-Sévrain S: Effect of estrogens on skin aging and the potential role of selective estrogen receptor modulators. Climacteric 2007; 10:289-297.

36 Richard S, Querleux B, Bittoun J, et al: Characterization of the skin in vivo by high resolu- tion magnetic resonance imaging: water behavior and age-related effects. J Invest Dermatol 1993;100:705-709.

37 Raine-Fenning NJ, Brincat MP, Muscat-Baron Y: Skin aging and menopause; implications for treatment. Am J Clin Dermatol 2003; 4:371-378.

38 Sato N, Kitahara T, Fujimura T: Age-related changes of stratum corneum functions of skin on the trunk and the limbs. Skin Pharmacol Physiol 2014;27:181

-39 Cerdà D, Peris P, Monegal A, et al: Identification of clinical features and laboratory abnormalities associated with the development of vertebral fractures in women with postmenopausal osteoporosis. Med Clin 2012;139:626630.

40 Zouboulis CC, Degitz K: Androgen action on human skin - from basic research to clinical significance. Exp Dermatol 2004;13:5-10.

-41 Choudhry R, Hodgins MB, Van der Kwast TK, et al: Localization of androgen receptors in human skin by immunohistochemistry: implications for the hormonal regulation of hair growth, sebaceous glands and sweet glands. J Endocrinol 1992;133:467-475.

42 Tadokoro T, Itami S, Hosokawa K, et al: Human genital melanocytes as androgen target cells. J Invest Dermatol 1997;109:513-517.

43 Lecce L, Lam YT, Lindsay LA, Yuen SC, Simpson PJ, Handelsman DJ, Ng MK: Aging impairs VEGF-mediated, androgen-dependent regulation of angiogenesis. Mol Endocrinol 2014;28:1487-1501.

44 Asada Y, Sonoda T, Ojiro M, et al: 5alpha-Reductase type 2 is constitutively expressed in the dermal papilla and connective tissue sheath of the hair follicle in vivo but not during culture in vitro. J Clin Endocrinol Metab 2001;86:2875-2880.

45 Yamazaki M, Sato A, Toyoshima KE, Kojima $Y$, et al: Polymorphic CAG repeat numbers in the androgen receptor gene of female pattern hair loss patients. J Dermatol 2011;38:680684.

46 Hillmer AM, Hanneken S, Ritzmann S, et al: Genetic variation in the human androgen receptor gene is the major determinant of common early-onset androgenetic alopecia. Am J Hum Genet 2005;77:140-148.

47 Paus R: The biology of hair follicles. N Engl J Med 1999;341:491-497.

-48 Yang YC, Fu HC, Wu CY, Wei KT, Huang KE, Kang HY: Androgen receptor accelerates premature senescence of human dermal papilla cells in association with DNA damage. PLoS One 2013;8:e79434.

49 Rosenfield RL: Hirsutism and the variable response of the pilosebaceous unit to androgen. J Investig Dermatol Symp Proc 2005;10:205208.

50 Deplewski D, Rosenfield RL: Role of hormones in pilosebaceous unit development. Endocrine Rev 2000;21:363-392.

51 Snyder PJ: Effects of age on testicular function and consequences of testosterone treatment. J Clin Endocrinol Metab 2001;86:2369-2372.
52 Khosla S, Melton LJ III, Atkinson EJ, et al: Relationship of serum sex steroid levels and bone turnover markers with bone mineral density in men and women: a key role for bioavailable estrogen. J Clin Endocrinol Metab 1996;83:2266-2274.

53 Burger HG, Dudley EC, Cui J, et al: A prospective longitudinal study of serum testosterone, dehydroepiendrosterone sulfate and sex hormone binding globulin levels through the menopause transition. J Clin Endocrinol Metab 2000;85:2832-2938.

54 Sowers MFR, Zheng H, McConnell D, et al: Testosterone, sex hormone-binding globulin and free androgen index among adult women: chronological and ovarian aging. Hum Reprod 2009;24:2279-2285.

55 Mitchell DL, Fernandez AA, Garcia R, et al: Acute exposure to ultraviolet- $B$ radiation modulates sex steroid hormones and receptor expression in the skin and may contribute to the sex bias of melanoma in a fish model. Pigment Cell Melanoma Res 2014;27:408-417.

56 Ji C, Yang Y, Yang B, et al: Trans-Zeatin attenuates ultraviolet induced down-regulation of aquaporin-3 in cultured human skin keratinocytes. Int J Mol Med 2010;26:257-263.

57 Seleit I, Bakry OA, El Rebey HS, et al: Is aquaporin-3 a determinant factor of intrinsic and extrinsic aging? An immunohistochemical and morphometric study. Appl Immunohistochem Mol Morphol 2015, E-pub ahead of print.

58 Pak TR, Chung WC, Roberts JL, et al: Ligandindependent effects of estrogen receptor beta on mouse gonadotropin-releasing hormone promoter activity. Endocrinology 2006;147: 1924-1931.

59 Nacusi LP, Debes JD: Primers on molecular pathways: nuclear receptors in pancreatic cancer. The ligand-independent way. Pancreatology 2008;8:422-424.

$60 \mathrm{Fu}$ XD, Simoncini T: Extra-nuclear signaling of estrogen receptors. IUBMB Life 2008;60: 502-510.

-61 Hibberts NA, Howell AE, Randall VA: Balding hair follicle dermal papilla cells contain higher levels of androgen receptors than those from non-balding scalp. J Endocrinol 1998; 133:141-147.

62 Parker MG: Structure and function of estrogen receptors. Vitam Horm 1995;51:267-287.

63 Heemers HV, Tindall DJ: Androgen receptor (AR) coregulators: a diversity of functions converging on and regulating the AR transcriptional complex. Endocr Rev 2007;28: 778-808.

64 Simoncini T, Genazzani AR: Non-genomic actions of sex steroid hormones. Eur J Endocrinol 2003; 148:281-292.

65 Bakry OA, Samaka RM, Shoeib MA, et al: Immunolocalization of androgen receptor and estrogen receptors in skin tags. Ultrastruct Pathol 2014;38:344-357.

66 Thornton MJ, Taylor AH, Mulligan K, et al: Estrogen receptor beta is the predominant estrogen receptor in human scalp skin. Exp Dermatol 2003;12:181-190. 